\title{
OCCURRENCE OF GARNETS WITH ECLOGITIC AND LHERZOLITIC COMPOSITIONS IN GARNET LHERZOLITE XENOLITH FROM THE CANASTRA-01 KIMBERLITE, BRAZIL
}

\author{
Dalla Costa*MM ${ }^{1}$, Santos RV ${ }^{1}$, Araújo DP ${ }^{1}$, Gaspar JC ${ }^{1}$ \\ ${ }^{1}$ Universidade de Brasília, Brasília, Brazil \\ *marinadalla@gmail.com
}

\section{INTRODUCTION}

Canastra-01 kimberlite is located in the Canastra Ridge region, Minas Gerais state, southeast Brazil. It is intrusive in the Proterozoic metassedimentary rocks of the Canastra Group, at the southeast border of the São Francisco Craton, a geological entity composed of archean blocks accreted and reworked during Paleoproterozoic and Neoproterozoic orogenies (Alkmim et al., 1993) (Figure 1).

The age calculated for the Canastra Kimberlite is $120 \pm 10$ ( $\mathrm{K}-\mathrm{Ar}$ in phlogopite) Ma (Pereira \& Fuck, 2005) and it is the first Brazilian kimberlite with proved economic diamond reserves (Chaves et al., 2008). It has sampled a large variety of mantle xenoliths, including lherzolites, harzburgites, dunites, pyroxenites and eclogites, and also crustal rocks. Previous studies of mineral chemistry and geothermobarometry carried out in these mantle xenoliths showed P-T arrays that spread between 40 to $60 \mathrm{~mW} / \mathrm{m}^{2}$ geotherms (Costa, 2008). The author proposes that these different geotherms are due to incomplete or even lack of re-equilibration of cratonic mantle portions during the last Proterozoic orogeny.

Most xenoliths are garnet lherzolites with mean modes of $65 \%$ of olivine, $5 \%$ of garnet, $10 \%$ of clinopyroxene and $20 \%$ of orthopyroxene. These rocks have mosaic porfiroclastic texture and rounded garnets with quelifitic alteration. Most pyroxene crystals show undulatory extinction and several have undergone recrystallization. In some samples they form trails of recrystallized grains that extend into the olivine neoblast matrix. Secondary minerals comprise phlogopite, which occur in a few samples, and serpentine that is found in all xenoliths.

\section{CAN-106 GRT LHERZOLITE XENOLITH}

Among the garnet lherzolite samples, CAN-106 outstood from the others due to the presence of three different colors of garnet: red, purple and orange, which were identified during mineral concentration procedures for $\mathrm{Sm}-\mathrm{Nd}$ isotopic analysis. The red garnet is the most abundant one (more than 90\%). The orange grains make about $7 \%$ and the purple variety corresponds to less than $1 \%$ of the xenolith's garnet grains.

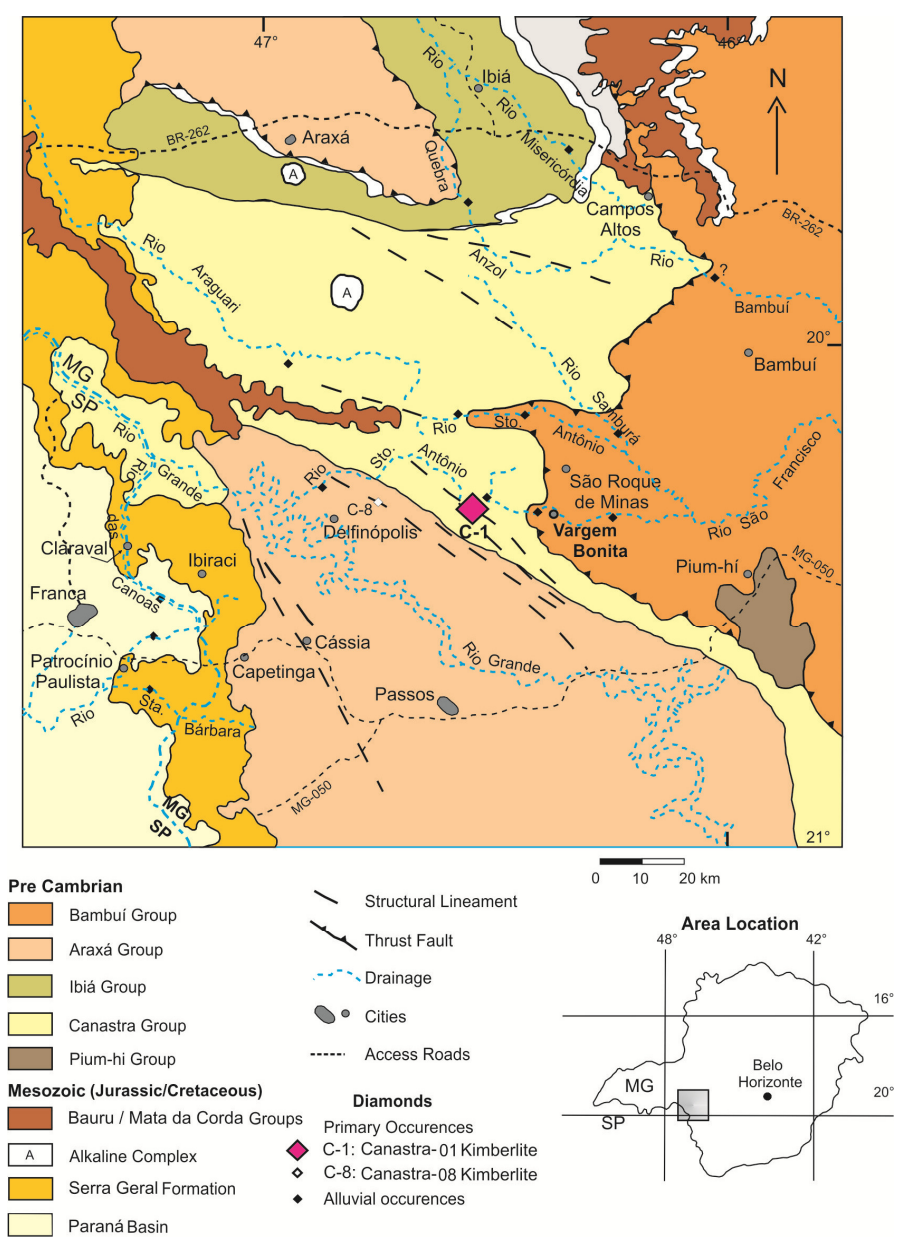




\section{$10^{\text {th }}$ International Kimberlite Conference, Bangalore - 2012}

Figure 1 - Simplified geological map of the Canastra Ridge region showing the location of Canastra-01 kimberlite (pink diamond - C-1). Modified from Chaves et al (2008).

Microprobe analyses were performed using $15 \mathrm{kv}$ and 10 na in a Jeol superprobe JXA-8230 at the University of Brasilia. The results indicated three main populations based on chemical composition. The first population has high $\mathrm{Cr}_{2} \mathrm{O}_{3}$ (7.08- $7.57 \mathrm{wt} \%$ ), medium $\mathrm{CaO}$ (5.99 to $6.66 \mathrm{wt} \%$ ) and $\mathrm{TiO}_{2}(0.06$ to $0.14 \mathrm{wt} \%)$, and $\mathrm{Mg}$ number from 0.83 to 0.85 . The second population has medium $\mathrm{CaO}(4.80-5.10 \mathrm{wt} \%)$ and $\mathrm{Cr}_{2} \mathrm{O}_{3}(3.00-3.65 \mathrm{wt} \%)$, high $\mathrm{TiO}_{2}(0.50-0.70 \mathrm{wt} \%)$, and $\mathrm{Mg}$ number from 0.83 to 0.84 . The third population has high $\mathrm{CaO}(9.75-10.09 \mathrm{wt} \%)$ and $\mathrm{TiO}_{2}(0.42-0.54 \mathrm{wt} \%)$, low $\mathrm{Cr}_{2} \mathrm{O}_{3}(0.03-0.15 \mathrm{wt} \%)$, and $\mathrm{Mg}$ number ranging between $0.59-0.60$.

According to Grütter et al (2004) garnet classification, the first and second populations have lherzolitic composition (G9), the third one has eclogitic composition (G3) (Figure 2). This group also has high $\mathrm{CaO}$ and $\mathrm{TiO}_{2}$ values that are comparable to those found in garnet related to diamond association paragenesis (Dawson \& Stephens, 1975).

Besides these three garnet populations, three grains that were analyzed presented $\mathrm{CaO}(5.95 \mathrm{wt} \%)$ and $\mathrm{Cr}_{2} \mathrm{O}_{3}(0.49$ wt $\%$ values compatible with low-Cr pyroxenitic/eclogitic/websteritic composition (G4). These grains also have 0.36 to $0.49 \mathrm{wt} \%$ of $\mathrm{TiO}_{2}$.

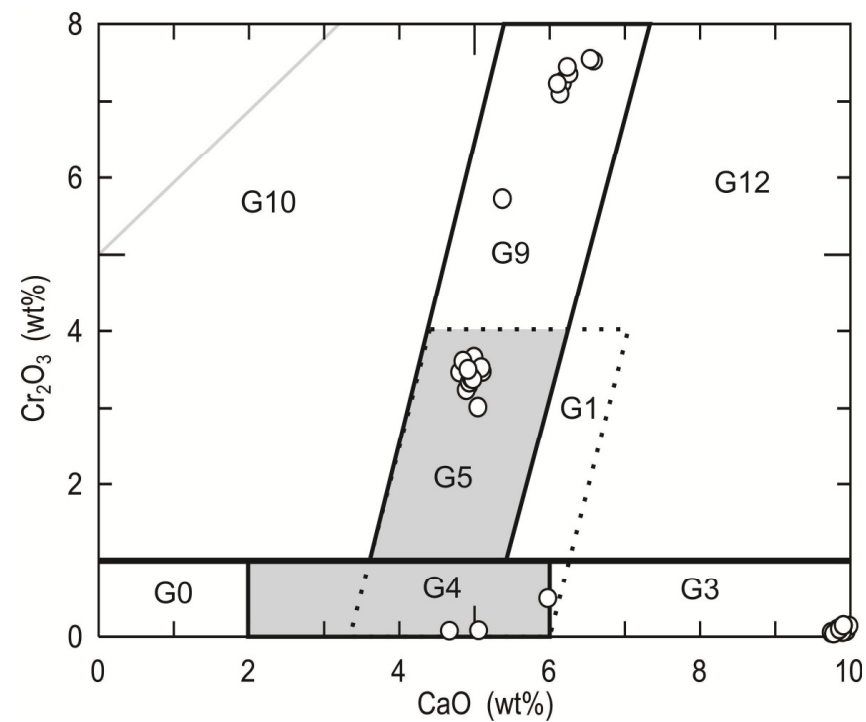

Figure 2 - CAN106 garnet classification according to the scheme presented by Grütter et al. (2004). G0: unclassified garnets; G1 (stippled parallelogram): low-Cr megacryst group; G3: eclogitic; G4 and G5: websteritic, pyroxenitic and eclogitic; G9: lherzolitic; G10: harzburgitic; G12: wehrlitic.

CAN106 hand specimen shows a zone with lighter matrix than the surroundings portions, with some garnet grains aligned, but no evidence of different material.
Microprobe analysis where performed in garnets from one thin section of the sample, but showed no compositional heterogeneities and all grains yielded lherzolitic compositions. However, this thin section did not reached the regions with textural variations observed in hand specimen, allowing speculations that the garnets with eclogitic composition might be related to such textural heterogeneities. Futher researches and analysis will be carried out on these different portions of the sample in order to verify this hypothesis.

The occurrence of garnet with eclogitic composition in a lherzolite xenolith is an uncommon feature in the mantle, thus requiring further textural and chemical investigation.

We suggest, however, that metassomatism and/or partial melting followed by crystallization might explain the chemical differences found in these garnet populations. This interpretation seems to be supported by preliminary Sm-Nd isotopic results for the Canastra-01 xenoliths that suggest that this kimberlite may have sampled a quite heterogeneous mantle.

\section{REFERENCES}

ALKMIM, F. F.; NEVES, B. B. B., ALVES, J. A. C. 1993. Arcabouço Tectônico do Cráton do São Francisco Uma Revisão. O Cráton do São Francisco, II Simpósio sobre o Cráton do São Francisco, Salvador, Bahia.

CHAVES, M. L. S. C.; ANDRADE, K. W.; BENITEZ, L.; BRANDÃO, P. R. G. 2008. Província Diamantífera da Serra da Canastra e o kimberlito Canastra-1: primeira fonte primária de diamantes economicamente viável do país. Geociências, UNESP, São Paulo, v 27, n. 3, p. 299-317.

COSTA, G. V. 2008. Química mineral e geotermobarometria de xenólitos mantélicos do kimberlito Canastra-01. Dissertação de mestrado $n^{\circ} 239$, Instituto de Geociências, Universidade de Brasília, 137 p.

DAWSON, J. B.; STEPHENS, W. E. 1975. Statistical classification of garnets from kimberlite and associated xenoliths. J. Geol. 83, 589-607.

GRÜTTER, H. S.; GURNEY, J. J.; MENZIES, A. H.; WINTER, F. 2004. An updated classification scheme for mantle-derived garnet, for use by diamond explorers. Lithos 77 841-857.

PEREIRA, R. S. \& FUCK, R. A. 2005. Archean nucleii and the distribution of kimberlito and related rocks in the São Francisco cráton, Brazil. Revista Brasileira de Geociências, v. 35, p. 93-104. 